The normality condition of data were averaged by Kolmogorov-Smirnov. Values of $\mathrm{p}<0.05$ indicate statistically significant.

The results show a decrease of mean blood flow velocity of the right $(p=0.18888)$ and left $(p=0.0071)$ middle cerebral arteries, mainly on the first minute of $\mathrm{HV}$, estimating a decrease of cerebral blood flow $(4.12 \%$ and $6.51 \%$, of the right and left middle cerebral arteries, respectively). Five minutes after $\mathrm{HV}$, there was a return to baseline values. In relation to gasometric parameters, there were a significant variation of $\mathrm{EtCO}_{2}$ and $\mathrm{PaCO}_{2}$ during the $\mathrm{HV}$, with smaller changes of $\mathrm{PaCO}_{2}$ in relation to $\mathrm{EtCO}_{2}$. The pulsatility index, another gasometric parameters, heart rate and mean arterial pressureremained stable during $\mathrm{HV}$.

Concluding, based on results of this study, that the maneuver of HV may be security applied and does not promote cerebral and systemic repercussion in studied patients.

KEY WORDS: hypenentilation, cerebral blood flow, transcranial Doppler.

* Repercussão da manobra de hiperventilação breve sobre a hemodinâmica cerebral, sistêmica e alterações gasométricas em pacientes sob assistência ventilatória mecânica (Resumo). Tese de Mestrado, Universidade Federal de Sergipe, UFS (Área: Ciências da Saúde). Orientador : Carlos Umberto Pereira.

** Address: Rua Oyapock 90/ 62, 80050-450 Curitiba PR, Brasil.

\title{
PHYSICAL EXERCISE INDUCES FUNCTIONAL RECOVERY AFTER SCIATIC NERVE TRAUMA IN RATS (ABSTRACT)*. THESIS. ARACAJU, 2006
}

\section{CARLOS MICHELL TÔRRES SANTOS **}

Recent studies show a probable relationship between physical training and functional recovery after a peripheral nerve lesion. Meanwhile, there is not na agre ement about what kind of physical training should be elected to obtain best results.

The present research verifies influence of predominant aerobic and anaerobic physical exercises on functional recovery process on days 5, 10, 15 and 20 after rat's sciatic nerve crush, by a non-invasive method called sciatic static index. Statistical analysis was made with 0.05 significance level.

With variance analysis application it was observed an increment on functional recovery by the tests accom- plished in days 15 and 20 after lesion to groups submitted to physical exercises. Latterly, it was employed Turkey test, which made possible to conclude that predominat aerobic and anaerobic exercises are not diffe rent on benefits offered in functional recovery process after peripheral nerve lesion.

Finally, two-way variance analysis demonstrated any influence in a significant manner the functional recovery process to analyzed groups, evidencing that physical exercises increase recuperation of nerve function.

KEY WORDS: sciatic trauma, physical exercise, functional recovery.

* O exercicio físico induz recuperação funcional pós-trauma do nervo ciático em ratos. (Resumo) Tese de Mestrado, Universidade Federal de Sergipe, UFS (Área: Ciências da Saúde). Orientador : Carlos Umberto Pereira,

** Address: Avenida Cezartina Regis 134, 49095-100 Aracaju SE, Brasil. E-mail michellfisio@hotmail.com

\section{ATTENTION-DEFICIT HYPERACTIVITY DISORDER SYMPTOMS AND SLEEP DISORDERS (ABSTRACT)*. DISSERTATION. CAMPINAS, 2006.}

\section{SÉRGIO NOLASCO HORA DAS NEVES**}

Objective: This study examined the relationship between Attention-Deficit Hyperactivity Disorder (ADHD) and sleep disorders to characterize clinical features and associated problems.

Method: In the first paper we review the researches literature about sleep disorders in children with ADHD with and without psychostimulant treatment. In the second paper we performed a record review of 50 consecutive children and adolescents aged 4 to 17 years with ADHD who do not have mental retardation or pervasive developmental disorders.

Results: Infants with sleep disorders were associat- 